\title{
Swachh Bharat Summer Internship Programme: An Opportunity of Community Based Service Learning Practice for Medical Students in India
}

\author{
Sourabh Paul ${ }^{1, *}$, Shyam Mehra ${ }^{2}$, Gurkirat Sidhu' ${ }^{2}$, Varun Malhotra ${ }^{2}$, Tanvir Kaur Sidhu' ${ }^{2}$, Paresh Prajapati ${ }^{2}$
}

Sourabh Paul ${ }^{1, *}$, Shyam

Mehra $^{2}$, Gurkirat Sidhu², Varun Malhotra², Tanvir Kaur Sidhu², Paresh Prajapati $^{2}$

'Department of Community Medicine, All India Institute of Medical Science, Raebareli, Uttar Pradesh, INDIA.

${ }^{2}$ Department of Community Medicine, Adesh Institute of Medical Science and Research, Bathinda, Punjab, INDIA.

\section{Correspondence}

\section{Dr. Sourabh Paul}

Assistant Professor, Department of Community Medicine All India Institute of Medical Science, Raebareli, Uttar Pradesh, INDIA

Mobile no: +91-08093424491

Email: drsourabh82@gmail.com

History

- Submission Date: 21-10-2020;

- Revised Date: 27-12-2020;

- Accepted Date: 16-02-2021;

DOI : 10.5530/ijmedph.2021.2.21

Article Available online

http://www.ijmedph.org/v11/i1

\section{Copyright}

(C) 2021 Phcog.Net. This is an openaccess article distributed under the terms of the Creative Commons Attribution 4.0 International license.

\begin{abstract}
Aim: "Swachh Bharat Summer Internship programme" is an initiative of Indian government to involve the youth of the country for cleanliness activity in the community. It was utilized by MBBS students of a university in Bathinda, India as a source of opportunity for community medicine learning and service in the community. Materials and Methods: A mixed method study was planned in the month of June 2019 to assess attitude of the community towards solid and liquid waste disposal, provide community service related with this and arrange health education sessions for waste disposal. Nukkad natak, focus group discussion and video clipping were used to educate community and data were collected. Cleaning of roads and market area were done as service to the community. Feedback from the community about different activities and from the students about the whole programme was collected \& analyzed. Results: Findings of the study have shown that villagers had a huge interest for different newer methods which were utilized for community health educational session. Similarly students had also liked the community service sessions however finding shows that requires some improvement in qualitative research techniques. Conclusion: Community's positive attitude towards waste disposal should be utilized judiciously for improving environmental cleanliness of the village. Similarly Positive feedback by the students' necessities that authority should conduct more and more community service and learning exercise involving different education model. Key words: Swachh Bharat Mission, Street drama, Health education, Focus group discussion, Health promotion.
\end{abstract}

\section{INTRODUCTION}

Prime Minister of India launched the Swachh Bharat Mission (SBM) on $2^{\text {nd }}$ October, 2014 to accelerate the efforts to achieve universal sanitation coverage and to put focus on safe sanitation. ${ }^{1}$ Following the enthusiastic response from the youth of India to the Swachh Bharat Abhiyan, the Ministry of Water and sanitation, in association with the Ministry of Youth Affairs and Sports and National Cadet Corps had launched the "Swachh Bharat Summer Internship" (SBSI) programme. The programme aims to engage youth across the country, develop their skills and orientation for Solid Waste Management (SWM) and sustain the momentum of the Swachh Bharat Janandolan. $^{2}$

In India, Community Medicine is synonymous with Public health. It is said that community is the laboratory for community Medicine. So, one of the objectives of community medicine curriculum is to make students aware about the behaviour and practices of the community that may affect their health and that is only possible when patient are seen as a part of community. Most of the time field visit of the under graduate students during community medicine posting is designed using a structured quantitative questionnaire based study with a specific objective. ${ }^{3}$ There is hardly any opportunity to get deep insight of a problem of the community. Here lies the importance of qualitative research. Qualitative research is a scientific method of observation to gather non-numerical data, while focusing on meaningmaking. This type of research answers questions related to why or how a certain phenomenon may occur, rather than how often it occurs. It helps in revealing the behaviour and perception of the community reference to a particular topic. ${ }^{4}$

Health education one of the strategy for health promotion, is a major weapon of community medicine practice. Practical exposure of different methods of health education during MBBS curriculum will increase the interest of the students towards the subject similarly it will improve their concept about the process which will be helpful for them while practicing medicine. ${ }^{5}$

So, best practicing way of real community medicine is by working with communities. "Swachh Bharat Summer Internship programme" has given an
Cite this article : Paul S, Mehra S, Sidhu G, Malhotra V, Sidhu TK, Prajapati P. Swachh Bharat Summer Internship Programme: An Opportunity of Community Based Service Learning Practice for Medical Students in India. Int J Med Public Health. 2021;11(1):118-23. 
opportunity to the undergraduate students to guide the community in different aspect of solid and liquid waste management through participation. Such engagement serves to unify the medical university's central domains of teaching, service and research into a coherent and cohesive institutional strategy for the near future. Present study was conducted with following objectives:

1. To provide health awareness related with solid and liquid waste management ( $S$ and LWM) among the villagers using different methods of health education.

2. To assess the community's attitude towards different methods of health education.

3. To provide Solid waste management related service to the community members.

4. To assess the skill of the MBBS students in conducting qualitative research work.

\section{MATERIALS AND METHODS}

A community based mixed method study was conducted in the month of June $15^{\text {th }}$ to $21^{\text {st }}$ June 2019 in the Bucho kalan village of Nathana block under Bathinda district of southern Punjab. The area comes under the field practice area of Department of Community Medicine, AIMSR, Bathinda. The village is having 1236 households and 7854 population. Study was a part of under graduate students "Swachh Bharat Summer Internship programme (SBSI)". 100 under graduate students of AIMSR, Bathinda had participated in the programme. Students had been divided in teen groups and each group was performing their activity in different part of the village. Day wise activity list is given below:

$1^{\text {st }}$ day activity: Focus group discussion in the community.

$2^{\text {nd }}$ day activity: Analysis of focus group discussion for next day health education session.

$3^{\text {rd }}$ day activity: Conduction of Nukad natak/ street drama and its related feed back.

$4^{\text {th }}$ day activity: Showing video clippings and its related feed back.

$5^{\text {th }}$ day Activity: Community service related activity.

$6^{\text {th }}$ day activity: Overall feedback and discussion about the programme in the department of community medicine.

\section{Focus group discussion}

Two students from each group had conducted one focus group discussion (FGD) each. Students were briefed about the objectives, steps and procedure of FGD in the Department of Community Medicine one day before the schedule activity as a method of preparation. On the day of activity activity students had conducted FGD for different group of people of the community. Each group had participation of average 8-10 participants. Numbers of FGDs conducted are as follows:

1. Adult males -2 FGDs

2. Adult females -2 FGDs

3. Elderly - 2 FGDs

4. Adolescent boys -2 FGDs

5. Adolescent girls - 2 FGDs

Participants was selected randomly who were available and given consent for participation. The focus of the FGDs was "Swachh Bharat Abhiyan" and its related activity. Each group had given the broad themes/ area for conduction of the FGD. Following are the areas for discussion in FGDs: i) solid and liquid waste management iii) knowledge of the community about sanitation and hygiene. i) "Swachh Bharat Abhiyan" and its related activity in the village". One student was making notes and also recording the whole FGD session. At the end of the session next day students were conducting the analysis of the FGDs. Content analysis were carried out by the students and later on categorization and grouping and then generation of theme was done. The whole session of the FGDs were under the observation of institute's faculty members who were trained in qualitative research. Faculty in charge of the group activity had given his feed back in 10 points Proforma about the FGDs performed by different group of students. Each component of the Proforma had a marking of 1-5. All the feedback were finally entered into an excel sheet and analysis was done using descriptive statistics.

\section{Information, Education and Communication (IEC) activities}

Based on the themes emerged from the focus group discussion students had conducted IEC activities to increase the awareness of people about sanitation related issues and trigger a change in sanitation related behaviour for solid and liquid waste management. Following are the list of IEC activities conducted by the students:

\section{Conduction of nukkad natak/ street drama}

Each group had conducted one nukkad natak. Each Nukkad natak was 7-8 min duration and 7-8 group members had participated in the Nukkad. There was one group member who was introducing the topic at the beginning and at the end he was summarizing the message or morale of the story. Each group there was one person for video recording the event. The whole nukkad natak was in local language (Punjabi). At the end of the nukkad natak villagers who were present and age $>10$ yrs were interviewed with a small questionnaire. Questionnaire had two parts part 1: demographic details of the participants and $2^{\text {nd }}$ part were related with nukkad natak. Sampling method followed here was convenient sampling. All the response of the participants were entered in a excel sheet and it was analyzed using descriptive statistics.

\section{Showing a small video clipping on "Swachh Bharat Abhiyan"}

Video clipping was of 3 min duration. It was shown to the villagers when the students visited the household. 10 students from each group had divided themselves in sub groups and each sub group having two students. Then students from each sub group visited as many as possible households to show the video clipping to the household members. All the adult members available at the time of visit were allowed to participate. The story of the video clipping was related to sanitation and hygiene. The language of the video clipping was in Hindi. Here also convenient sampling method was followed for data collection. At the end of the session each participants were similarly interviewed using a predesigned structured Proforma. Proforma had both open ended and closed questions. All the responses were finally entered into an excel sheet and analysis was done using descriptive statistics.

\section{Community service}

Next day of the programme students had visited the households in the village in a group of two students. Total number of household in the village had 1234 so each group of two students had visited at least 25 households to collect the garbage. All the collected garbage was then taken away from the village and disposed by scientific method. Students also had done cleaning of the roads of the village. At the time of household visit students had done community awareness through interpersonal communication method if they found any problem in $\mathrm{S}$ and LWM. 


\section{Feedback from the students}

Final day of the programme students had been distributed a feedback questionnaire to collect their response about the activity. Feedback Proforma had two parts: $1^{\text {st }}$ part demographic variables of the participants and $2^{\text {nd }}$ part question pertaining to the activities.

During the period of research, we followed the ethical guidelines of ICMR. Informed written consent was taken from the participants where possible. Confidentiality and anonymity were maintained during the study. Necessary approval was taken from the institutional ethics committee before conducting the study.

\section{RESULTS}

\section{Focus group discussion}

Table 1 shows the characteristics of the villagers participated in the FGD.

\section{Major them or area appeared from the FGD were}

Both solid and liquid, biodegradable as well as non-biodegradable waste are problem of the village

$\mathrm{S}$ and LWM is a big problem for the community. Neither government nor the public are focused specifically on this problem. Types of solid waste which were generated by the community were both biodegradable and non-biodegradables. Example: cow dung, kitchen waste, kitchen water, hay straw, construction material, plastic material etc. FGDs had highlighted that:

"People are piling up cow dung in front of their houses" (FGD -3, 4, 5, 7)

"Kitchen water goes into the road, no drainage and even if it is there most of the time it is uncovered drain" (FGD-1,2,9)

"No body is bother about plastic waste throwing it here and there even in the drain also" (FGD- 1,7, 8).

Table 1: Characteristics of the participants in focus group discussion.

\begin{tabular}{|c|c|c|c|c|}
\hline Type 1 & $\begin{array}{l}\text { Participants } \\
\text { (n) }\end{array}$ & Gender & $\begin{array}{c}\text { Age range } \\
\text { (yrs) }\end{array}$ & $\begin{array}{l}\text { Type of } \\
\text { group }\end{array}$ \\
\hline $\begin{array}{c}\text { Focus group } \\
1\end{array}$ & 8 & M & $30-37$ & Adult Male \\
\hline $\begin{array}{c}\text { Focus group } \\
2\end{array}$ & 7 & M & $33-41$ & Adult Male \\
\hline $\begin{array}{c}\text { Focus group } \\
3\end{array}$ & 9 & $\mathrm{~F}$ & $29-41$ & Adult female \\
\hline $\begin{array}{c}\text { Focus group } \\
4\end{array}$ & 6 & F & $31-51$ & Adult female \\
\hline $\begin{array}{c}\text { Focus group } \\
5\end{array}$ & 8 & $\mathrm{M}$ and $\mathrm{F}$ & $62-69$ & Elderly \\
\hline $\begin{array}{c}\text { Focus group } \\
6\end{array}$ & 9 & $\mathrm{M}$ and $\mathrm{F}$ & $65-72$ & Elderly \\
\hline $\begin{array}{c}\text { Focus group } \\
7\end{array}$ & 7 & M & $13-19$ & $\begin{array}{c}\text { Adolescent } \\
\text { boys }\end{array}$ \\
\hline $\begin{array}{c}\text { Focus group } \\
8\end{array}$ & 6 & M & $11-17$ & $\begin{array}{l}\text { Adolescent } \\
\text { boys }\end{array}$ \\
\hline $\begin{array}{c}\text { Focus group } \\
9\end{array}$ & 8 & $\mathrm{~F}$ & $14-18$ & $\begin{array}{l}\text { Adolescent } \\
\text { girls }\end{array}$ \\
\hline $\begin{array}{c}\text { Focus group } \\
10\end{array}$ & 9 & F & $13-19$ & $\begin{array}{l}\text { Adolescent } \\
\text { girls }\end{array}$ \\
\hline
\end{tabular}

\section{Causes of improper solid waste disposal}

The themes emerged regarding the hindrance of proper solid and liquid waste disposal were highlighted by the participants of FGDs. Lack of political commitment, ignorance of the community members about the scientific method of disposal of waste, less involvement of female in decision making related with sanitation and hygiene, high cost of disposal etc.

"Politicians are busy about toilet construction they have hardly any interest of the disposal of garbage, drainage system of the community" (FGD - 1, 8, 9)

"Hardly anybody knows about the segregation of waste at source, recycling of waste. Health care providers are less interested to teach us. It is same story running for years". (FGD-7,810)

"Swachh Bharat Abhiyan" are in papers nobody knows what is going on. Especially females' don't have any role in it." $(3,4,5)$

\section{Possible remedies}

Massive awareness generation is required about the waste management system of the community. Government, teachers, health care providers, Panchayat, politicians had to come forward.

"Politicians should be told by the villagers if you want vote arrange for proper waste disposal” (FGD - 1,5,6).

"Kitchen waste, cow dung can be disposed simply by vermicomposting method but it requires Panchayat, health workers to make people aware about this". (FGD- 7, 8, 9).

\section{Assessment of the FGD sessions by faculty members}

Performance of the different group of students in conducting FGDs under 10 points. Proforma has shown that students had well conducted welcoming of the participants, addressing main questions and giving closing remarks. Whereas students require more skills on preparation of the $\mathrm{C}$ shaped sitting arrangement, role of moderator or involvement of the all the participants in group discussion and coding and theme generation (Table 2)

\section{Nukkad natak/ Street drama}

10 groups of students had performed nukkad natak on three different themes. The themes were:

1. Water stagnation, mosquito breeding and related disease: 4 groups

2. Segregation of general waste at source and their proper disposal: 3 groups

3. Sources of e-waste and there proper disposal: 3 groups

Table 2: Assessment of FGDs by faculty members.

\begin{tabular}{cc|}
\hline Components of the FGD & Mean score of the groups \pm SD \\
Welcome & $4.2 \pm .31$ \\
Sitting arrangement & $2.5 \pm .52$ \\
Participants consent & $3.8 \pm .78$ \\
Introduction of the topic & $3.8 \pm .91$ \\
Opening questions & $3.2 \pm .82$ \\
Main questions & $4.3 \pm .21$ \\
Involvement of all the participants & $2.4 \pm .61$ \\
Closing remarks & $4.0 \pm .66$ \\
Transcript preparation & $3.9 \pm .23$ \\
Coding and theme generation & $2.1 \pm .42$
\end{tabular}


Total number of villagers was present as viewer at the time of nukkad natak was 745 . So average number of viewers present in each episode of nukkad natak was 75 . Out of these 80 viewers was less than 10 yrs age group. So they were not asked questions related to the attitude towards nukkad natak. So remaining viewers was 665. Demographic characteristics of the viewers: Male: $36 \%$ vs. Female: $64 \%$; Age group (10-40 yrs): $29.8 \%$ vs $>40$ yrs: $70.2 \%$; Educational status: up to primary education: $25.1 \%$ vs. Secondary education and above: $74.9 \%$.

$90 \%$ of the viewers had told that they had never witnessed any nukkad natak on these topics in past in their village. $85.7 \%$ of the viewers had understood the messages given by the nataks. More than $70 \%$ had the opinion that the topics were relevant considering their village. $78.3 \%$ viewers want to practice the things whatever shown in the nukkad nataks and more than $70 \%$ had the opinion that nukkad natak can be used more as a medium for community health education. Few suggestions put forward by the viewers for nukad natak was a) functional good quality audio system should be used b) Timing of the activity should be communicated to the villagers well in advance.

Table 3 shows the association between demographic variables and attitude of the viewer's towards nukkad natak. Middle age and elderly (age $>40$ yrs) as well as higher educational status viewers had significantly more in favour of the opinion that selection of the topic is appropriate for their village. Similarly Middle age and elderly (age $>40 \mathrm{yrs}$ ), female and less educated viewer had the opinion that nukkad natak should be a medium for community health education and this was found significant.

\section{Video clippings}

Total number of viewers for video clippings was 1033. Out of these 201 viewers was less than 10 yrs age group. So they were not asked questions related to the attitude towards video clippings. So remaining viewers was 832.

Demographic characteristics of the participants were Male vs. female ( $35.1 \%$ vs. $64.9 \%$ ), age group $<40$ yrs vs. $\geq 40$ yrs ( $43 \%$ vs. $57 \%$ ), educational status: up to primary $36.2 \%$ vs. secondary and above $63.8 \%$. $85.1 \%$ of the viewers had liked the video clippings whereas $76.6 \%$ of the viewers had understood the messages given by the video. Video clippings had given three messages: a) water stagnation and related disease b) segregation of solid waste and their disposal, c) plastic waste management. Out of the three massages all the three messages were understood by $38 \%$ of the viewers, $58 \%$ understood at least two messages and $76.6 \%$ of at least one message. 9 out of 10 viewers want this kind of health educational messages in their mobile regularly. Table 4 shows that age, gender and educational status don't hold any significant relationships between liking and understanding the messages of the video clippings. But younger age group, male and upper educational status viewers had the opinion that they want regularly this kind of video clippings in their mobiles for health education. Majority had told that this kind of activity they had never seen in their community. Few suggestions put forwarded by the viewers were the video clippings should be in local language, the duration of the video should be more and one message should be given in one video clipping.

Table 3: Association between demographic variables and attitude of the viewer's towards nukkad natak/ street drama.

\begin{tabular}{|c|c|c|c|c|c|c|c|c|}
\hline \multirow[t]{3}{*}{ Variable } & \multicolumn{8}{|c|}{ Attitude of the viewers } \\
\hline & \multicolumn{2}{|c|}{$\begin{array}{l}\text { Understood about the } \\
\text { message of the nukkad } \\
\text { natak }\end{array}$} & \multicolumn{2}{|c|}{$\begin{array}{l}\text { Selection of the topic is } \\
\text { appropriate for your village }\end{array}$} & \multicolumn{2}{|c|}{$\begin{array}{l}\text { Do you want to practice } \\
\text { whatever shown in the nukkad } \\
\text { in your daily life }\end{array}$} & \multicolumn{2}{|c|}{$\begin{array}{l}\text { Nukkad natak is a medium for } \\
\text { community education }\end{array}$} \\
\hline & Yes (\%) & No (\%) & Yes (\%) & No (\%) & Yes (\%) & No (\%) & Yes (\%) & No $(\%)$ \\
\hline \multicolumn{9}{|l|}{ Age } \\
\hline $10-40$ yrs & $170(85.9)$ & $28(14.1)$ & $\begin{array}{l}112 \\
(56.6)\end{array}$ & $86(43.4)$ & $\begin{array}{l}151 \\
(76.3)\end{array}$ & $47(23.7)$ & $70(35.4)$ & $\begin{array}{l}128 \\
(64.6)\end{array}$ \\
\hline$>40$ yrs & $400(85.7)$ & $67(14.3)$ & $375(80.3)$ & $92(19.7)$ & $370(79.2)$ & $97(20.8)$ & $410(87.8)$ & $\begin{array}{l}57 \\
(12.2)\end{array}$ \\
\hline Chi square & 0.004 & & 39.95 & & 0.721 & & 190.4 & \\
\hline$P$ value & 0.944 & & 0.0001 & & 0.395 & & 0.0001 & \\
\hline \multicolumn{9}{|l|}{ Sex } \\
\hline Male & $\begin{array}{l}201 \\
(87.5)\end{array}$ & $39(12.5)$ & $170(70.8)$ & $\begin{array}{l}70 \\
(29.2)\end{array}$ & $\begin{array}{l}190 \\
(79.2)\end{array}$ & $\begin{array}{l}50 \\
(20.8)\end{array}$ & $160(66.7)$ & $\begin{array}{l}80 \\
(33.3)\end{array}$ \\
\hline Female & $\begin{array}{l}369 \\
(86.8)\end{array}$ & $56(13.2)$ & $317(74.6)$ & $108(25.4)$ & $\begin{array}{l}331 \\
(77.9)\end{array}$ & $\begin{array}{l}94 \\
(22.1)\end{array}$ & $320(75.3)$ & $\begin{array}{l}105 \\
(24.7)\end{array}$ \\
\hline Chi square & 1.183 & & 1.103 & & 0.149 & & 5.685 & \\
\hline$P$ value & 0.276 & & 0.293 & & 0.699 & & 0.017 & \\
\hline \multicolumn{9}{|c|}{ Educational status } \\
\hline Up to primary & $\begin{array}{l}146 \\
(87.4)\end{array}$ & $\begin{array}{l}21 \\
(12.6)\end{array}$ & $\begin{array}{l}96 \\
(57.5)\end{array}$ & $\begin{array}{l}71 \\
(42.5)\end{array}$ & $\begin{array}{l}131 \\
(78.4)\end{array}$ & $\begin{array}{l}36 \\
(21.6)\end{array}$ & $\begin{array}{l}141 \\
(84.4)\end{array}$ & $\begin{array}{l}26 \\
(15.6)\end{array}$ \\
\hline $\begin{array}{l}\text { Secondary and } \\
\text { above }\end{array}$ & $\begin{array}{l}424 \\
(85.1)\end{array}$ & $\begin{array}{l}74 \\
(14.9)\end{array}$ & $\begin{array}{l}391 \\
(78.5)\end{array}$ & $\begin{array}{l}107 \\
(21.5)\end{array}$ & $390(78.3)$ & $\begin{array}{l}108 \\
(21.7)\end{array}$ & $\begin{array}{l}339 \\
(68.1)\end{array}$ & $\begin{array}{l}159 \\
(31.9)\end{array}$ \\
\hline Chi square & 0.5331 & & 28.2 & & 0.0012 & & 16.66 & \\
\hline$P$ value & 0.465 & & 0.001 & & 0.971 & & 0.0001 & \\
\hline
\end{tabular}




\section{Community service}

For providing community service students had used 100 brooms, 100 packets of bleaching powder, garbage bags, 100 litre of phenyl etc. They had cleaned the roads, Gurdwara and market area of the village. A tractor was used to collect and transport the garbage out of the village for scientific method of disposal. Students had also demonstrated the villagers how to dispose vegetable peels, food, farm waste, kitchen waste etc easy but scientific method called vermicomposting. They have also demonstrated the villagers how to segregate biodegrable and nonbiodegrable waste. Cleaning of the drains also had been performed by the students. Villagers also participated in the cleaning activity (Figure 1).

\section{Feedback of the students}

Following are the feedback of the students who had participated in the programme. Majority of the participants $(82.1 \%)$ had liked the activities and among them $54 \%$ had told that community service was the most satisfying event whereas $35 \%$ had the satisfaction from participating in nukkad natak. Male students had significantly more affection for the community service compared to the female $(p=0.043)$. Major three learning of the students identified by them was: a) conduction of a focus group discussion (81.3\%) b) organizing successfully a social and community service programme $(71.4 \%)$ c) learning the art of nukkad natak (53.2\%). Students had also few suggestions regarding the teaching learning and service point of view for future: a) more frequent organization of similar activity in future b) Local Panchayat should take more responsibility so that maximum number of villagers can participate c) opportunity for debriefing session for the community with the findings of the activity.

\section{DISCUSSION}

One of the objectives of Swachh Bharat abhiyan of motivating community to adopt sustainable sanitation practice in relation to solid and liquid waste disposal is only possible by increasing their awareness as well as practical demonstration of this scientific method of waste disposal to them. "Swachh Bharat Summer Internship programme" is an opportunity to involve the youth of the community so that they can learn by doing it. It is an opportunity for the MBBS students also for community learning as well as service delivery. Class room based pedagogy lined with service -learning practical experiences had a paramount importance in the training of $21^{\text {st }}$ century public health curriculum.

Health education is the process of imparting information about health in such a way that the recipient is motivated to use that information for the protection of advancement of his own, his family's or his community's wealth. ${ }^{6}$ The problem of S and LWM and their proper disposal had been highlighted in the form of nukkad natatk that is one of the best methods for community learning especially in rural India. ${ }^{7}$ Elderly and middle age, female and less educated had more positive opinion for nukkad natak which is in agreement with another study conducted in rural Harayana. ${ }^{7}$ Similarly short video film on S and LW disposal also

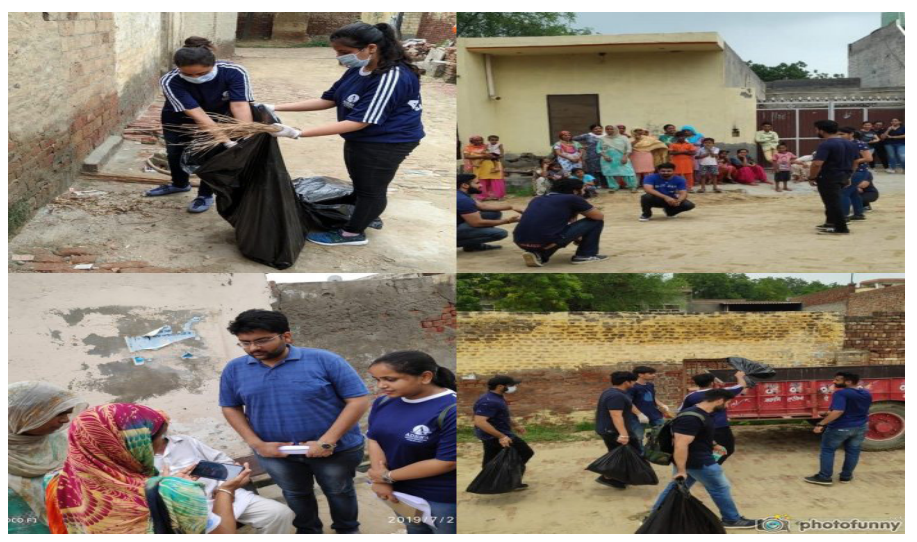

Figure 1: Community service under the Swachh Bharat Summer Internship programme.

Table 4: Association between demographic variable and attitude of the viewer's towards video clippings.

\begin{tabular}{|c|c|c|c|c|c|c|}
\hline \multirow[t]{3}{*}{ Variable } & \multicolumn{6}{|c|}{ Attitude towards video clippings } \\
\hline & \multicolumn{2}{|c|}{ Have you liked the video clippings } & \multicolumn{2}{|c|}{$\begin{array}{c}\text { Have you understood the message of the } \\
\text { video clippings }\end{array}$} & \multicolumn{2}{|c|}{$\begin{array}{c}\text { Do you want regularly this kind of video } \\
\text { clippings in mobile }\end{array}$} \\
\hline & Yes (\%) & No (\%) & Yes (\%) & No (\%) & Yes (\%) & No (\%) \\
\hline \multicolumn{7}{|l|}{ Age } \\
\hline$<40 \mathrm{yrs}$ & $301(84.1)$ & $57(15.9)$ & $267(74.6)$ & $91(25.4)$ & $332(92.7)$ & $26(7.3)$ \\
\hline$\geq 40 \mathrm{yrs}$ & $407(85.9)$ & $67(14.1)$ & $370(78.1)$ & 104(21.9) & $419(88.4)$ & $55(11.6)$ \\
\hline$P$ value & 0.473 & & 0.241 & & 0.036 & \\
\hline \multicolumn{7}{|l|}{ Sex } \\
\hline Male & $251(86.0)$ & $41(14.0)$ & $226(77.4)$ & $66(22.6)$ & $281(96.2)$ & $11(3.8)$ \\
\hline Female & $457(84.6)$ & $83(15.4)$ & $411(76.1)$ & $129(23.9)$ & $471(87.2)$ & $70(12.8)$ \\
\hline Up to primary & $261(86.7)$ & $40(13.3)$ & $219(72.8)$ & $82(27.2)$ & $258(85.7)$ & $43(14.3)$ \\
\hline $\begin{array}{l}\text { Secondary and } \\
\text { above }\end{array}$ & $447(84.2)$ & $84(15.8)$ & $418(78.7)$ & $113(21.3)$ & $493(92.8)$ & $38(7.2)$ \\
\hline Chi square & 0.969 & & 3.80 & & 11.11 & \\
\hline$P$ value & 0.324 & & 0.051 & & 0.0008 & \\
\hline
\end{tabular}


Paul, et al:: SBSI: A Community Basesd Service Learning Practice Opportunity for Medical Students

had attracted the attention of the viewers and it was more favoured by the young, male and educated participants. A study conducted Burkina Faso also had highlighted that short videos on mobile had the potential of an effective health promotion tool. ${ }^{8}$ Since the numbers of mobile users are increasing even in rural India the new innovative ideas of health education can be explored however due consideration should be given to the age, gender, educational status, culture etc. ${ }^{9}$ Advantage of these activities for the MBBS students is they had the feeling of the rural community, their culture and also a first had interaction with them.

Study suggests any community education session is always helpful when it is designed according to the felt need of the community. ${ }^{10}$ In this present study students had done this exercise using focus group discussion and based on the finding health educational session was planned. The benefit of the FGD is that it allows students to find out indepth information about the felt need of the community also to gather different views, perceptions and ideas of the villages. Present exercise has shown that students had hands on training of one of the important model of epidemiological exercise (FGD) which was mainly remain untouched during MBBS curriculum. However observation of the faculty members suggests that they require few more practical sessions to master on it. A study conducted in Chennai has shown that research skills of fresh MBBS graduates are very poor in India both in qualitative as well as quantitative research. ${ }^{11}$ Community social service provided by the students in the form of road cleaning, garbage collection and demonstration of scientific method of their disposal is a classical exhibition of "lead by example". It is rightly said that "our mind remembers what we see" so health education in the form of demonstration has the better influence among the community compared to others. ${ }^{6}$ Study has shown that this kind of service learning process builds and refines someone's team based skills; improve mental maturity of the students to resolve obstacles etc. ${ }^{12}$

Positive feedback by the students has opened the door for similar kind of service and learning activity for future. Model of community service and learning should be encouraged more among the MBBS students by celebrating different national health days in the community and in these activity different models of health education [e.g. -street theatre, theatre in education (TIE) or drama in education (DIE)] can be used. ${ }^{6,13}$ Similarly sharing of the study findings with community leaders is also important for community participation. Present study was done only in one village of Bathinda, Punjab which may not be representation of all the villages of Punjab. There was not much educational session for the children $<10$ yrs age group but this is the period of life when practices of sanitation and hygiene should be developed.

\section{CONCLUSION}

Community Medicine must be learned in the community as the community is the "heart" of the system of health care. ${ }^{14}$ Community service and learning model of present study has shown that villagers have a huge interested for social drama or newer methods of community education with variation of age, gender and educational status. Their positive attitude towards waste disposal should be utilized judiciously for improving environmental cleanliness of the village. Positive feedback by the students' necessities that authority should conduct more and more community service and learning exercise involving different educational model (e.g.: focus group discussion etc).

\section{ACKNOWLEDGEMENT}

We want to thank all the community members for their active participation.

\section{CONFLICT OF INTEREST}

The authors declare that there is no conflict of interest.

\section{ABBREVIATIONS}

SBM: Swachh Bharat Mission; SBSI: Swachh Bharat Summer Internship; SWM: Solid Waste Management; S and LWM: Solid and liquid waste management; AIMSR: Adesh Institute of Medical Science and Research; FGD: focus group discussion; IEC: Information, Education and Communication.

\section{REFERENCES}

1. Guidelines for Swachh Bharat Mission (Gramin). Ministry of drinking water and sanitation. Government of India. 2018. (Revised December 31, 2018). [Cited 14 April 2020]. Available from: http://swachhbharatmission.gov.in/sbmcms/ writereaddata/images/pdf/Guidelines/Complete-set-guidelines.pdf

2. Swachh bharat Summer Internship 2.0 for youth. Nehru Yuva Kendra Sangathan Department of Youth Affairs. Ministry of youth affairs and sports, Govt of India. 2019. [Cited 15May 2020]. Available from: https://nyks.nic.in/Newlnitiatives/ SwachhBharatIntership/Guidline-\%20Targets, \%20Strategies $\% 20$ and\%20 Awards \%20for \% 20\%20\%20Swach \%20Internship-Final\%20.pdf

3. Howard DE, Rao CR, Desmond SM. Borrowing from the East to Strengthen the West: Merging Public Health Case Studies of Community-Based Service Learning Practices from India and the United States. Journal of Community Practice. 2010;18(2-3):336-60

4. Qualitative research. Wikipedia. 2020. [Cited 15 May 2020]. Available from https://en.wikipedia.org/wiki/Qualitative_research

5. Saha A, Poddar E, Mankad M. Effectiveness of different methods of health education: A comparative assessment in a scientific conference. BMC Public Health. 2005;5(1):88.

6. Tevatia S, Sharma N, Chopra R. Role of drama in oral health education: The point of view of dental Student. Journal of Formulation Science and Bioavailability. 2017; 1(1):1000113

7. Amin W, Naqshbandi MM. Effective awareness generation methods for rural sanitation campaign: A study from a village in Haryana. International Journal of Sociology and Anthropology. 2013;5(3):78-83.

8. Swigart T, Hollowell J, Remes P, Lavoie M, Murray J, Belem M, et al. Can health promotion videos 'go viral'? A non randomized, controlled, before and after pilot study to measure spread and impact of local language mobile videos in Burkino Faso. Global Health Action. 2019;12(1):1-8

9. Mitter S. India's internet population is growing older and more rural: In Mobi. 2019. Available from: https://yourstory.com/2019/02/indias-internet-populationgrowing-older-mo-kw6uutau2f

10. Wade JL. Felt needs and anticipatory needs: Reformulation of a basic community development principle. Journal of Community Development Society. 1989;20(1):116-23.

11. Anusuya GS, Arumugam B, Sucharitha ST, Karthik RC, Radharishnan A, Sivapriya KRS, et al. Evaluation of research sills of medical interns by focus group discussion: A qualitative study in Chennai, India. International Journal of Community Medicine and Public Health. 2018;5(10):4258-62.

12. Loh AZH, Tan JSY, Lee JJM, Koh GC. Voluntary community service in medical school: A qualitative study on obstacles faced by student leaders and potential solutions. Global Health Action. 2015;8(1):27562

13. Banerjee A. Evaluating the roles of street theatre for social communication Global Media Journal-Indian Edition. 2013;4(2):1-18.

14. Lal S, Kumar R, Prinjia S, Singh GPI. Post graduate teaching and evaluation in community medicine: challenges ahead. Indian J Prev Soc Med. 2011;42(3):2205 . 